\title{
Correction to: The wealth decumulation behavior of the retired elderly in Italy: the importance of bequest motives and precautionary saving
}

\section{Luigi Ventura $^{1} \cdot$ Charles Yuji Horioka ${ }^{2,3,4,5}$}

Published online: 22 February 2021

(c) The Author(s) 2021

\section{Correction to: Review of Economics of the Household https://doi.org/10.1007/s11150-020-09486-y}

The article "The wealth decumulation behavior of the retired elderly in Italy: the importance of bequest motives and precautionary saving", written by Luigi Ventura and Charles Yuji Horioka, was originally published electronically on the publisher's internet portal on 30 April 2020 without open access. With the author(s)' decision to opt for Open Choice the copyright of the article changed on 3 February 2021 to (C) The Author(s) 2021 and the article is forthwith distributed under a Creative Commons Attribution 4.0 International License, which permits use, sharing, adaptation, distribution and reproduction in any medium or format, as long as you give appropriate credit to the original author(s) and the source, provide a link to the Creative Commons licence, and indicate if changes were made. The images or other third party material in this article are included in the article's Creative Commons licence, unless indicated otherwise in a credit line to the material. If material is not included in the article's Creative Commons licence and your intended use is not permitted by statutory regulation or exceeds the permitted use, you will need to obtain permission directly from the copyright holder. To view a copy of this licence, visit http://crea tivecommons.org/licenses/by/4.0.

The original article can be found online at https://doi.org/10.1007/s11150-020-09486-y.

Charles Yuji Horioka

horioka@rieb.kobe-u.ac.jp

1 Department of Economics and Law, Sapienza, University of Rome, Rome, Italy

2 Research Institute for Economics and Business Administration, Kobe University, 2-1, Rokkodai-cho, Nada-ku, Kobe, Hyogo 657-0813, Japan

3 Institute of Social and Economic Research, Osaka University, Ibaraki, Japan

4 Asian Growth Research Institute, Kitakyushu, Japan

5 National Bureau of Economic Research, Cambridge, MA, USA 